\title{
Florida Darkwinged Subterranean Termite, Amitermes floridensis Scheffrahn, Su, and Mangold (Insecta: Isoptera: Termitidae: Termitinae) ${ }^{1}$
}

Rudolf H. Scheffrahn and Nan-Yao Su${ }^{2}$

\section{Introduction}

As a member of the highly specialized termite family Termitidae, Amitermes floridensis is unique among all termites found in the eastern United States. Occurring only in Florida, it is an ancient scrubland relic of a once broad distribution of Amitermes that extended across Texas and the Gulf region. Although astute pest control operators knew of this termite decades before, Amitermes floridensis was not described until 1989 from specimens collected in St. Petersburg, Florida. It is the most recent native termite species to be recognized in the United States.

\section{Distribution}

Amitermes floridensis has a spotty distribution in west central Florida in a region bordered by Tarpon Springs to the north, Punta Gorda to the south, and Sebring to the east. Reports by pest control operators and collection data indicate that Pinellas County has the greatest urban abundance of $A$. floridensis in the State with most of the activity limited to St.

Petersburg.

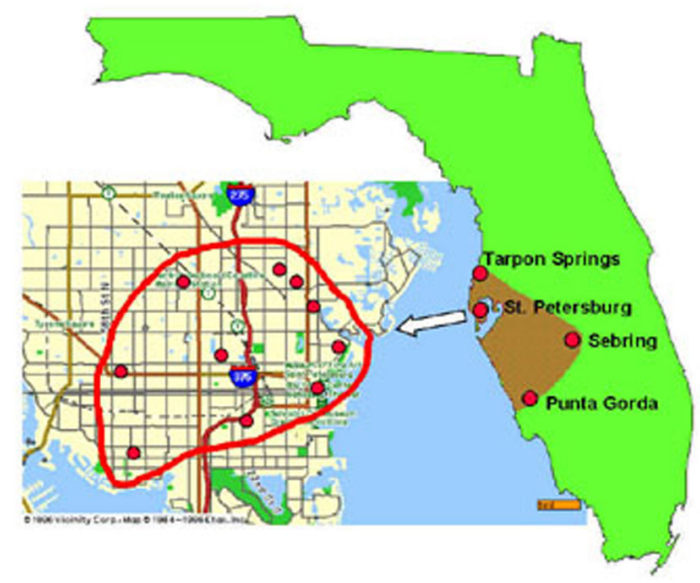

Figure 1. Distribution of the Florida darkwinged subterranean termite, Amitermes floridensis Scheffrahn, $\mathrm{Su}$, and Mangold. Credits: Rudolf H. Scheffrahn, University of Florida

\section{Description and Identification}

As with other subterranean termites, $A$. floridensis builds a system of foraging galleries that connect the nest chambers in the soil with feeding sites above and below the ground. Colonies of $A$. floridensis consist of three primary castes: the

1. This document is EENY-112, one of a series of the Entomology and Nematology Department, Florida Cooperative Extension Service, Institute of Food and Agricultural Sciences, University of Florida. Original publication date August 1999. Reviewed May 2003. Visit the EDIS Web Site at http://edis.ifas.ufl.edu.

2. Rudolf H. Scheffrahn, professor and Nan-Yao Su, professor, Entomology and Nematology Department, Ft. Lauderdale - REC, University of Florida, Ft. Lauderdale, FL.

The Institute of Food and Agricultural Sciences (IFAS) is an Equal Opportunity Institution authorized to provide research, educational information and other services only to individuals and institutions that function with non-discrimination with respect to race, creed, color, religion, age, disability, sex, sexual orientation, marital status, national origin, political opinions or affiliations. U.S. Department of Agriculture, Cooperative Extension Service, University of Florida, IFAS, Florida A. \& M. University Cooperative Extension Program, and Boards of County Commissioners Cooperating. Larry Arrington, Dean 
reproductives (king, queen, unmated winged forms called alates, and immatures called nymphs), soldiers, and workers. The workers of $A$. floridensis are true sterile adults. They cannot molt and will not become reproductives or soldiers. The workers excavate soil and feed on wood to nourish themselves and their nestmates. Deeper into the nest, young whitish termites, called larvae, and eggs can be found. The king and queen live furthest into the nest system and attempts to collect them have been unsuccessful. The queens of other Amitermes species have greatly enlarged abdomens for massive egg production. Soldiers and alates have the most obvious characters for species identification, but workers of $A$.

floridensis can also be distinguished from other subterranean termites found in Florida. All castes except for the nymphs and alates are present in colonies year round.

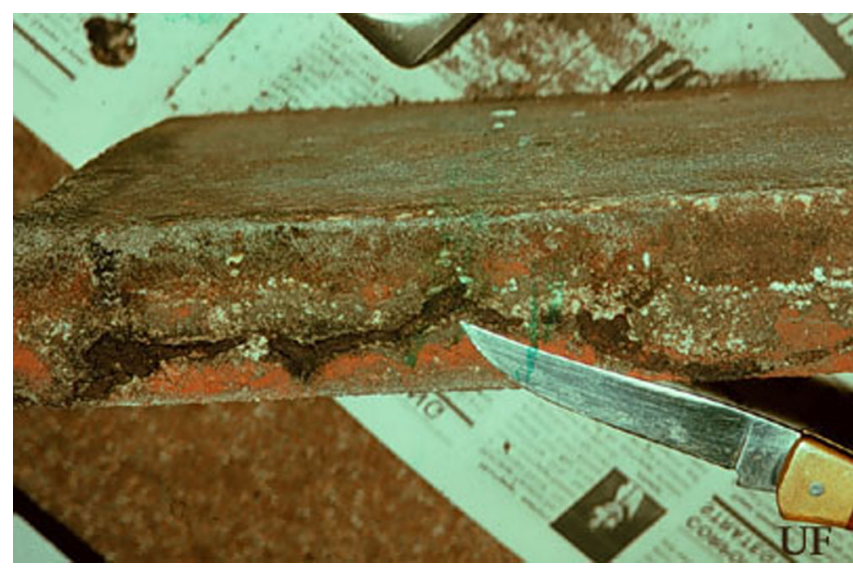

Figure 2. Broken foraging tube of the Florida darkwinged subterranean termite, Amitermes floridensis Scheffrahn, $\mathrm{Su}$, and Mangold, on patio stone to expose black fecal coating. Credits: Rudolf H. Scheffrahn, University of Florida

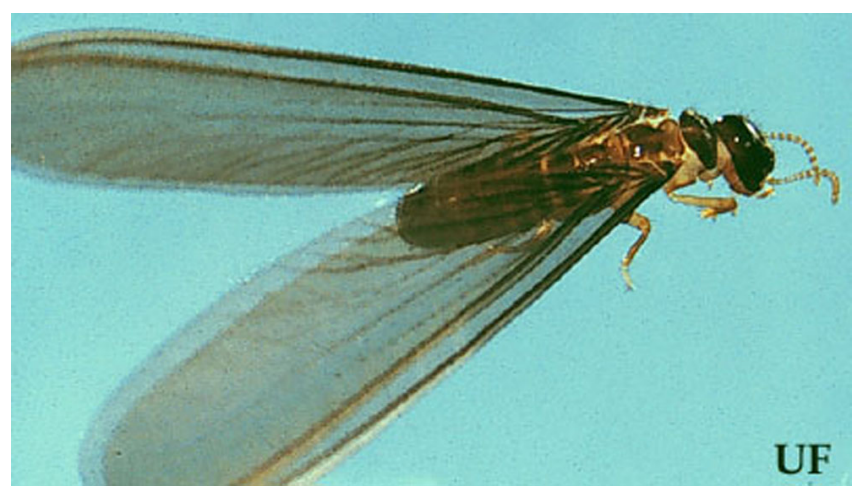

Figure 3. Alate of the Florida darkwinged subterranean termite, Amitermes floridensis Scheffrahn, Su, and Mangold. Credits: Rudolf H. Scheffrahn, University of Florida

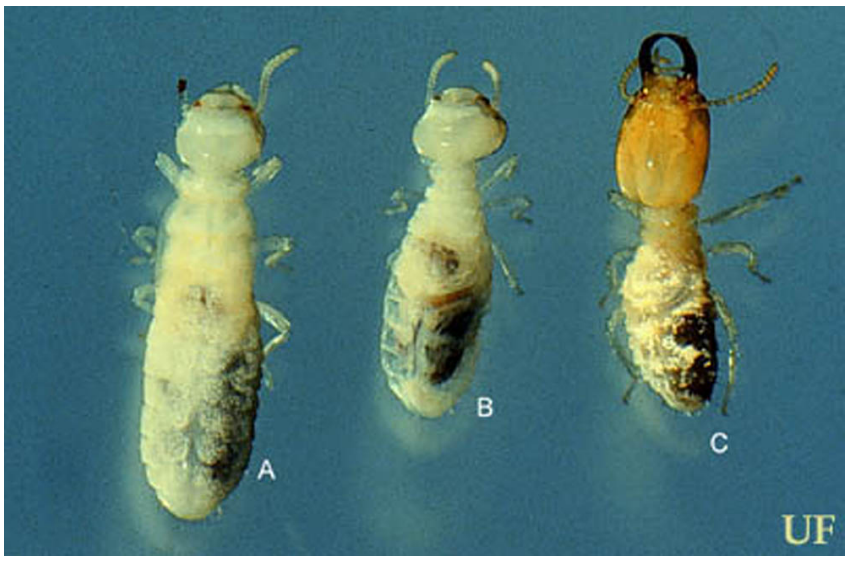

Figure 4. Nymph (A), worker $(B)$ and soldier $(C)$ of the Florida darkwinged subterranean termite, Amitermes floridensis Scheffrahn, Su, and Mangold. Credits: Rudolf $\mathrm{H}$. Scheffrahn, University of Florida

Amitermes floridensis alates develop from nymphs that appear in the colony before flight season. Nymphs resemble large workers but have wing pads and often have less abdominal coloration than workers. Alates are small and have two pairs of smoothly textured and darkly pigmented wings that are about equal in size and shape. Each wing has two darkened and enlarged veins (subcosta and radial sector) in their leading (costal) margins. The upper surfaces of the head, thorax, and abdomen of alates appear dark brown to black. The alate body is about 0.15 inches $(4 \mathrm{~mm})$ in length without wings and 0.35 inches $(9 \mathrm{~mm})$ with wings. Shed wings are about 0.3 inches $(7 \mathrm{~mm})$ long and appear disproportionately large for the size of the alate body.

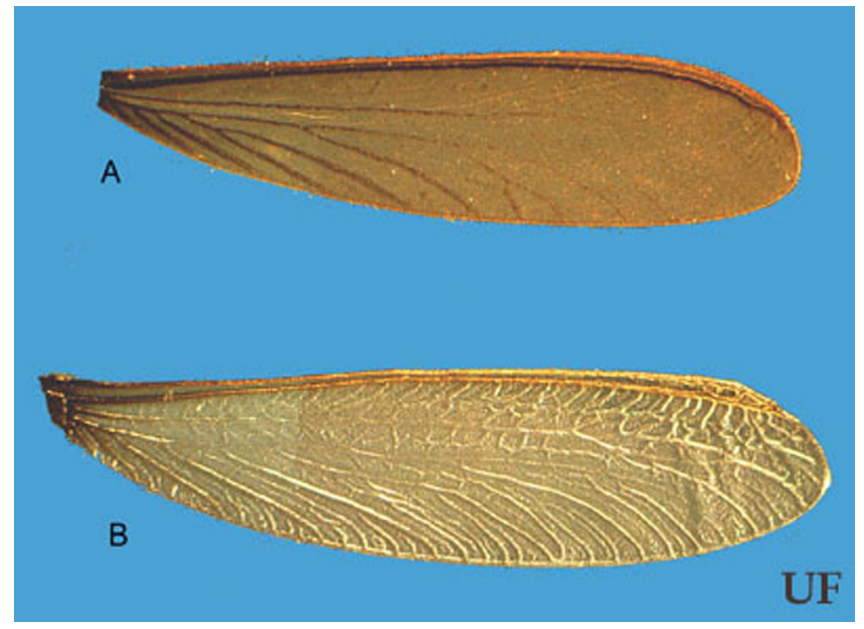

Figure 5. comparison of the wings of the Florida darkwinged subterranean termite, Amitermes floridensis Scheffrahn, Su, and Mangold (A), and the eastern subterranean termite, Reticulitermes flavipes (Kollar) (B). Credits: Rudolf H. Scheffrahn, University of Florida 
The soldiers are very small (less than $3.5 \mathrm{~mm}$ long) and have a bulbous orange head and black, sickle- shaped mandibles. They differ from other subterranean termites in Florida by having a prominent conical tooth near the base of each mandible. The soldiers have an opening near the front of the head called the fontanelle through which is secreted a mixture of ant-repelling, volatile compounds called sesquiterpenoids.

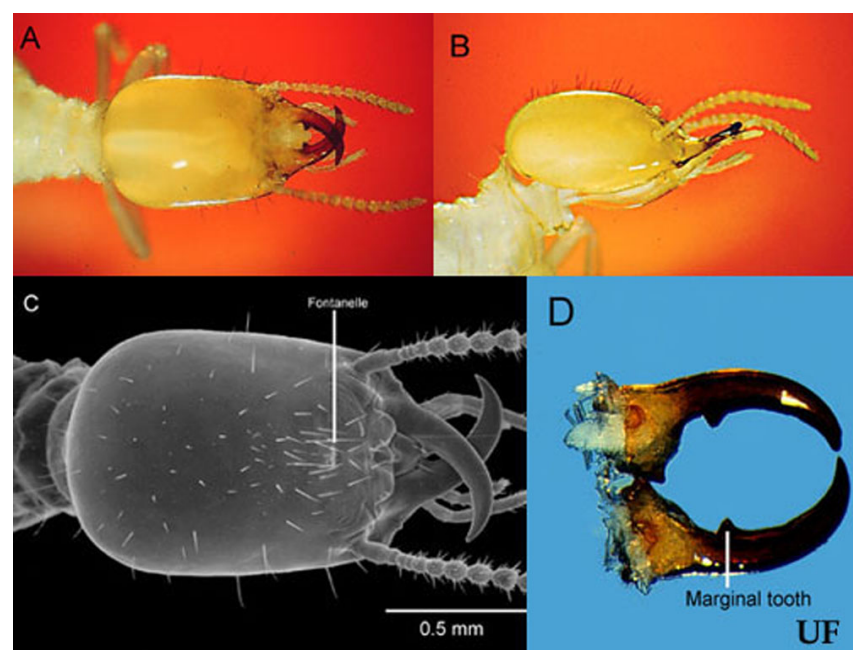

Figure 6. Soldier of the Florida darkwinged subterranean termite, Amitermes floridensis Scheffrahn, Su, and Mangold; dorsal $(A)$ and lateral $(B)$ views of soldier head capsule; scanning electron micrograph (C) of dorsal view of soldier head capsule; dissected soldier mandibles (D). Credits: Rudolf H. Scheffrahn, University of Florida

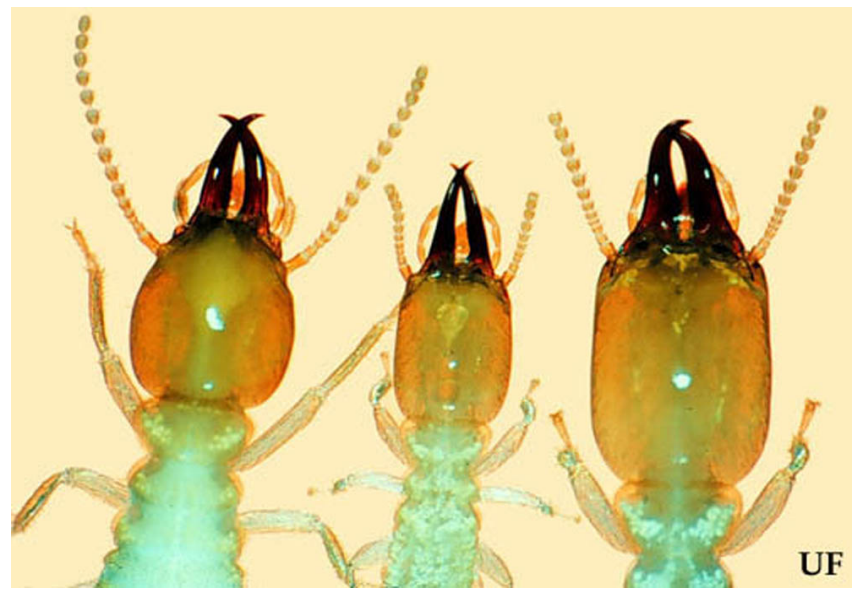

Figure 7. Size comparison of soldiers of the eastern subterranean termite, Reticulitermes flavipes (Kollar) (A), and the Florida darkwinged subterranean termite, Amitermes floridensis Scheffrahn, Su, and Mangold (B). Credits: Rudolf H. Scheffrahn, University of Florida

Workers of A. floridensis are about the same size as soldiers, but workers lack the defensive structures and coloration of the soldier head capsule. The workers move more slowly than those of other subterranean termites and have a more constricted thorax and inflated abdomen giving them a "plump" appearance compared with workers of native subterranean termites in the genus Reticulitermes. The abdominal wall is transparent and the coiled digestive tube is filled with dark fecal contents that give the abdomen a distinctive gray color.

\section{Life History}

In the spring of each year, nymphs appear in mature colonies. The nymphs molt into alates that leave the colony during a series of dispersal flights over the summer. Alates of A. floridensis launch themselves from free-standing tunnels called "swarm tubes". Alates are restricted to flights in calm air during or immediately after rain showers. Flights occur during daylight hours from July to September in contrast to the springtime flights for other subterranean termite species in Florida. These dispersal flights or "swarms" are often massive and a witness once described a series of alate launches as looking like plumes of smoke coming from the ground. There are no reports of indoor flights. The alates are weak fliers and are often found adhering en masse to wet vehicles, buildings, and vegetation. After a brief flight, the alates shed their wings and segregate into male/female pairs. Males follow females in tandem in search of subterranean nest sites under wood, stones, and other surface debris near food. After many years of growth, successful colonies mature to produce their first crop of alates.

\section{Damage}

Unlike most other subterranean termites in the eastern United States, A. floridensis workers tend to graze wood surfaces instead of excavating them with galleries. Foraging tunnels are built over feeding sites and are covered with characteristic black fecal lining. Attacked wood may be partially decayed and is often in direct contact with the soil such as fallen branches, tree trunks, fence posts, and storage sheds. Although colonies may be large and foraging tunnels extensive below ground, A. floridensis forages only short distances above ground in search of food sources. Therefore, structural infestations are usually limited 


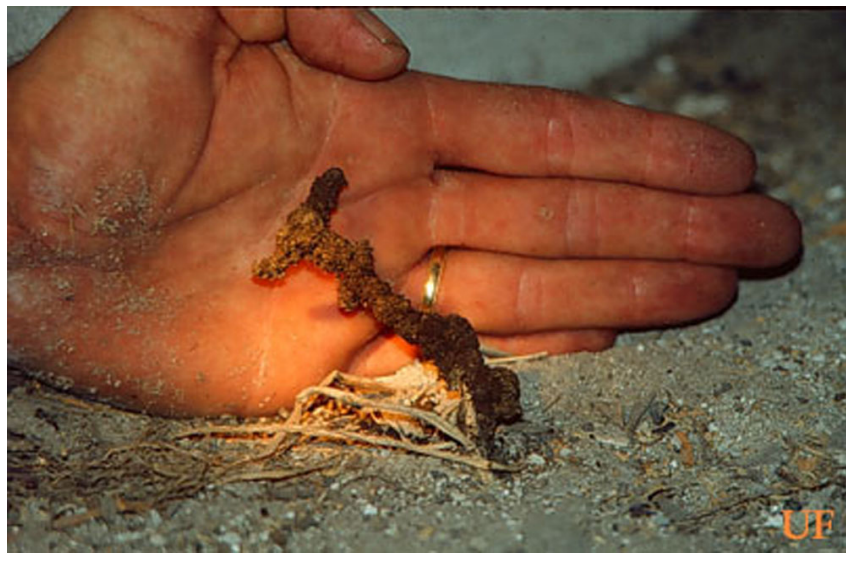

Figure 8. Free standing foraging/flight tunnel of the Florida darkwinged subterranean termite, Amitermes floridensis Scheffrahn, Su, and Mangold, extending from sandy soil. Credits: Rudolf H. Scheffrahn, University of Florida

to porches, door frames, carpet tack strips, and foundation elements where foragers gain entry through cracks and joints.

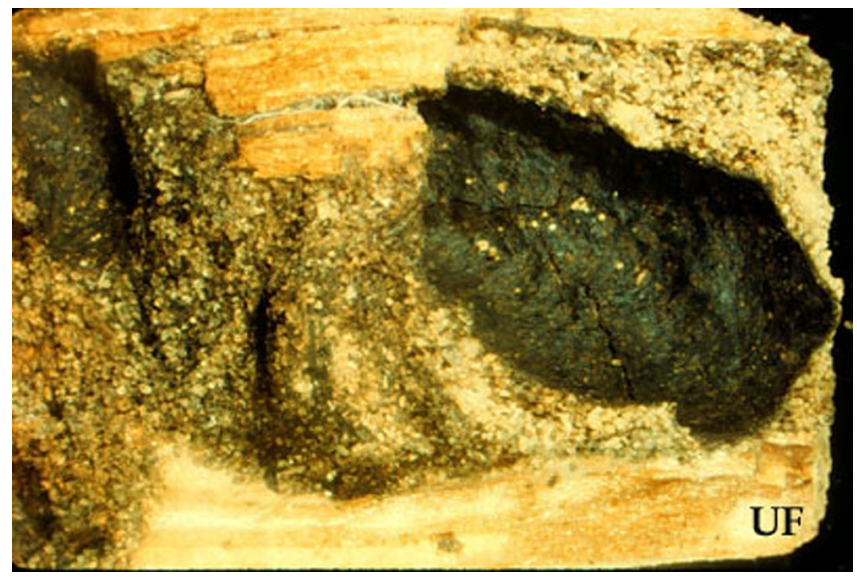

Figure 9. Partially broken foraging tube of the Florida darkwinged subterranean termite, Amitermes floridensis Scheffrahn, Su, and Mangold, in decayed 2x4 board showing black fecal coating. Credits: Rudolf H. Scheffrahn, University of Florida

\section{Pest Status}

For reasons mentioned above, A. floridensis is an uncommon structural pest. Wood damage is usually minor, however alates, wings, and foraging tubes are a sanitary nuisance.

\section{Management}

As with all subterranean termites, wood-to-ground contact should be avoided. In structures, chemical barriers should be applied as "spot" treatments in areas were the termites are

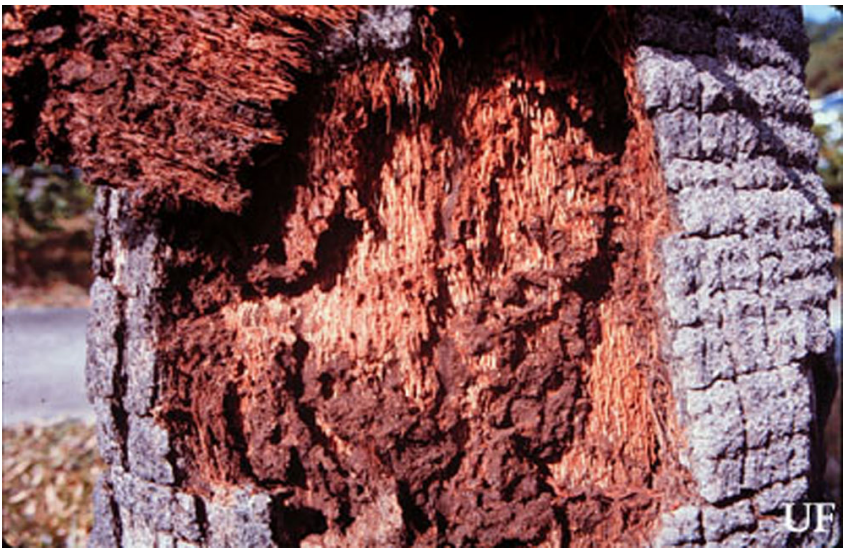

Figure 10. Foraging tubes and workings of the Florida darkwinged subterranean termite, Amitermes floridensis Scheffrahn, Su, and Mangold, to a palm trunk in St. Petersburg, Florida. Credits: J.R. Mangold

suspected of emerging from the soil. Because of their limited foraging potential, extensive barrier treatments beyond the immediate area of the infestation are usually not warranted. This species is known to enter and feed inside termite bait stations although the efficacy of baits against $A$. floridensis is unknown. In baits containing insect growth regulators, any effect would be protracted because the workers do not molt so only the developing young would be affected.

\section{Selected References}

Scheffrahn, R.H., L.K. Gaston, J.J. Sims, and M.K. Rust. 1983. Identification of the defensive secretion from soldiers of the North American termite, Amitermes wheeleri (Desneux) (Isoptera: Termitidae). J. Chem. Ecol. 9: 1293-1305.

Scheffrahn, R. H., J. R. Mangold, and N.-Y. Su. 1988. A survey of structure-infesting termites of peninsular Florida. Florida Entomol. 71: 615-630.

Scheffrahn, R. H., N.-Y. Su, and J. R. Mangold. 1989. Amitermes floridensis, a new species and first record of a higher termite in the eastern United States (Isoptera: Termitidae: Termitinae). Florida Entomol. 72: 618- 625 .

Scheffrahn, R.H. and N.-Y. Su. 1994. Keys to soldier and winged adult termites (Isoptera) of Florida. Florida Entomol. 77: 460-474. 
Scheffrahn, R. H., N.-Y. Su, and J. R. Mangold. 1990. A new termite species in Florida: Amitermes floridensis. PCO, Off. Mag. Florida Pest Control Assn., Oct., cover and pp. 10-14.

Scheffrahn, R.H. and N.-Y. Su. Key to termite soldiers of Florida. Ft. Lauderdale Research Report 96-2.

Scheffrahn, R.H. and N.-Y. Su. Key to winged termites of Florida. Ft. Lauderdale Research Report 96-3. 